\title{
GOMPHONEMA VIBRIO VAR. SUBCAPITATUM (BACILLARIOPHYCEAE), NEW FOR POLAND
}

\author{
MONIKA ELIASZ-KowALSKA
}

\begin{abstract}
Gomphonema vibrio var. subcapitatum (A. Mayer) J. H. Lee, hitherto unknown in Poland, is reported here from six lakes in the northeastern part of the country. This diatom prefers alkaline waters of medium conductivity and low nitrate and chlorine concentrations. The taxon is documented by SEM images and LM micrographs, and its morphological variability and distribution are briefly discussed.
\end{abstract}

Key words: diatom, distribution, ecology, freshwater, Gomphonema, lakes, Wigry National Park

Monika Eliasz-Kowalska, Institute of Nature Conservation, Polish Academy of Sciences, Al. Mickiewicza 33, 31-120 Kraków, Poland; e-mail: eliasz@iop.krakow.pl

\section{INTRODUCTION}

Diatoms of the genus Gomphonema Ehrenb. are common and abundant, living attached to various kinds of substrate in diverse freshwater habitats (wood, plants, rocks, sand grains). Several of them have clearly defined environmental tolerance ranges and therefore are used as bioindicators (e.g., Picińska-Fałtynowicz \& Błachuta 2010; Hofmann et al. 2011; Bąk et al. 2012).

During studies of diatom material collected in 2010-2016 in Wigry National Park, northeastern Poland (Fig. 1), I identified an interesting member of the genus Gomphonema - G. vibrio var. subcapitatum (Mayer) Lee. The taxon is reported here as new for Poland. A brief description is given, with SEM images and LM micrographs of specimens. Notes on its ecology and worldwide distribution are provided.

\section{STUDY AREA, MATERIAL AND METHODS}

Ten lakes of the Pojezierze Suwalskie lakeland in northeastern Poland, all located in Wigry National Park, were studied: Muliczne Lake, Okrągłe Lake, Białe Pierciańskie, Białe Wigierskie Lake, Krusznik Lake, Wygorzele Lake, Suchar III Lake, Suchar Wielki Lake, Wądołek Lake and Wigry Lake. These lakes were formed during the Baltic phase of the last glaciation. Gomphonema vibrio var. subcapitatum was found in six of them (Fig. 1).
Their basic characteristics, including trophy of the waterbodies, are given in Table 1.

The material was collected in 2010-2016 from Phragmites australis Trin. ex Steud. Additionally, 13 herbarium samples collected in 1994-2004 were included.

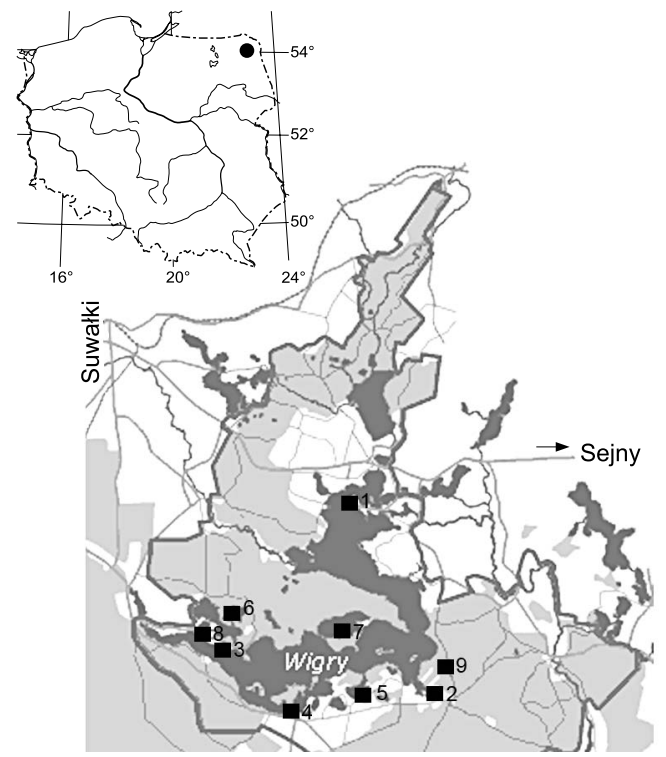

Fig. 1. Study area. 1-4 - Wigry Lake (1 - near Wigry Wieś, 2 - Zatoka Krzyżańska bay, 3 - Zatoka Uklei bay, 4 - near Bryzgiel), 5 - Krusznik Lake, 6 - Muliczne Lake, 7 - Białe Wigierskie Lake, 8 - Okrągłe Lake, 9 - Wygorzele Lake. 
Table 1. General characteristics of six lakes with Gomphonema vibrio var. subcapitatum (Mayer) Lee in Wigry National Park (after Górniak 2006).

\begin{tabular}{lrrrl}
\hline Lake & $\begin{array}{r}\text { Max. } \\
\text { deph } \\
{[\mathrm{m}]}\end{array}$ & $\begin{array}{r}\text { Lake } \\
\text { area } \\
{[\mathrm{ha}]}\end{array}$ & $\begin{array}{r}\text { Direct } \\
\text { catch- } \\
\text { ment } \\
{[\mathrm{ha}]}\end{array}$ & Trophy \\
\hline Muliczne & 11.3 & 24.1 & 191.2 & Hypertrophic \\
Okrągłe & 13.0 & 13.7 & 28.5 & Eutrophic \\
Białe Wigierskie & 34.0 & 99.9 & 329.1 & Mesotrophic \\
Krusznik & 18.0 & 26.7 & 70.7 & Hypertrophic \\
Wygorzele & 3.0 & 2.0 & 63.5 & Dystrophic \\
Wigry & 73.0 & 2118.0 & 5159.8 & Eutrophic \\
\hline
\end{tabular}

Fresh samples were preserved in $c a 4 \%$ solution of formalin. Laboratory processing of diatoms for fresh samples and herbarium samples followed the method used in the manual of the Polish Water Framework Directive (Picińska-Fałtynowicz \& Błachuta 2010). To remove the organic matter, samples were macerated in $c a 30 \%$ hydrogen peroxide at room temperature for ca 2 weeks, after which hydrochloric acid was applied to remove calcium carbonate and the samples were rinsed in a centrifuge ( 5 min., 3 times). The cleaned diatom valves were embedded in Naphrax synthetic resin. $G$. vibrio var. subcapitatum was observed in 25 of the many samples studied. For estimation of its relative abundance, 400 diatom frustules per sample were counted using a Nikon Eclipse-80i light microscope. A Hitachi S-4700 scanning electron microscope was used to identify valve detail. The identification of $G$. vibrio was based mainly on Reichardt and Lange-Bertalot (1991) and Hofmann et al. (2011).

\section{RESULTS AND DISCUSSION}

\section{Gomphonema vibrio var. subcapitatum (Mayer)}

Lee

Figs 2-14, 21-25

Korean J. Phycol. 7(1): 86. 1992 - Gomphonema intricatum var. vibrio f. subcapitatum Mayer, Denk. Bayer. Bot. Ges. 17: 121: pl. 4, f. 17, 18. 1928.

Valves 46-76 $\mu \mathrm{m}$ long, 8.0-11.2 $\mu \mathrm{m}$ wide with 8-9 striae in $10 \mu \mathrm{m}$, and 20-25 areolae in $10 \mu \mathrm{m}$ (Figs 2-7, 9-11). Valve margin near apical pole rounded or slightly capitate (Figs 2-7, 9-12), basal pole narrowly rounded (Figs 2-7, 9-11, 14); both poles with heavily silicified pseudosepta (Figs 12, $14,23,24)$. Middle part of valve slightly swollen
(Figs 2-7, 9-11, 13, 21, 22, 25). Striae towards the footpole and headpole much denser than in the mid-valve (Figs 2-7, 9-11, 13, 21, 22, 25). Uniseriate striae weakly radial in mid-valve portion, becoming more radiate towards headpole and footpole (Figs 2-7, 9-14, 21-25), expanding to valve mantle (Fig. 8). Areolar openings small, round located in shallow row. Side walls of areolae bear pair of small struts (Figs 23-25). Isolated pore with round opening located distant from long central stria (Figs 2-7, 9-11, 13). Internal opening of isolated pore (stigma) small, elliptical, located in long groove. Opposite valve side with stigma are 1-2 very short striae (Figs 2, 3, 5, 6, 9, 11, 13 ) or no striae (Figs 4, 7). Axial area widened toward central area (Figs 2-7, 9-11, 21, 22). Internal opening of isolated pore small, elliptical, located in long groove (Fig. 25). Inner distal raphe fissures terminate within distinctly silicified helictoglossa (Figs 23, 24).

The observed valves of $G$. vibrio var. subcapitatum from Poland fall within the known range of morphological variability of this diatom as emended by Lee et al. (1992a).

The samples with $G$. vibrio var. subcapitatum were collected in the spring, summer and fall, and the variety was always rare (ca $1 \%)$. It was found in 21 fresh samples from six lakes: $\mathrm{Mu}-$ liczne (3 samples), Okrągłe (3 samples), Białe Wigierskie (3 samples), Krusznik (3 samples) and Wigry (3 samples from Zatoka Krzyżańska bay, 2 from the vicinity of Wigry Wieś village, 3 from Zatoka Uklei bay), Wygorzele (1 sample), and in four herbarium samples from Muliczne (1994), Okrągłe (1995), Białe Wigierskie (1996) and Krusznik (2004).

The ionic composition of the water from the sampling sites was as follows: phosphate $\left(\mathrm{PO}_{4}{ }^{3-}\right)$ $<0.015 \mathrm{mg} \mathrm{L}^{-1}$, nitrate $\left(\mathrm{NO}_{3}^{-}\right)<1.4 \mathrm{mg} \mathrm{L}^{-1}$, chlorine $\left(\mathrm{Cl}^{-}\right) 2-17 \mathrm{mg} \mathrm{L}^{-1}$, calcium $\left(\mathrm{Ca}^{2+}\right) 0.85-$ $68.00 \mathrm{mg} \mathrm{L}^{-1}$ and sulphate $\left(\mathrm{SO}_{4}{ }^{2-}\right) 1.2-31.0 \mathrm{mg} \mathrm{L}^{-1}$; $\mathrm{pH}$ was $4.0-8.3$ and conductivity $25-395 \mu \mathrm{S} \mathrm{cm} \mathrm{L}^{-1}$. Gomphonema vibrio var. subcapitatum was least abundant in Wygorzele (spring, less than 0.25\%) and most abundant in Krusznik (fall, 1.5\%), Muliczne (spring and fall, 1.5\%) and Białe Wigierskie 

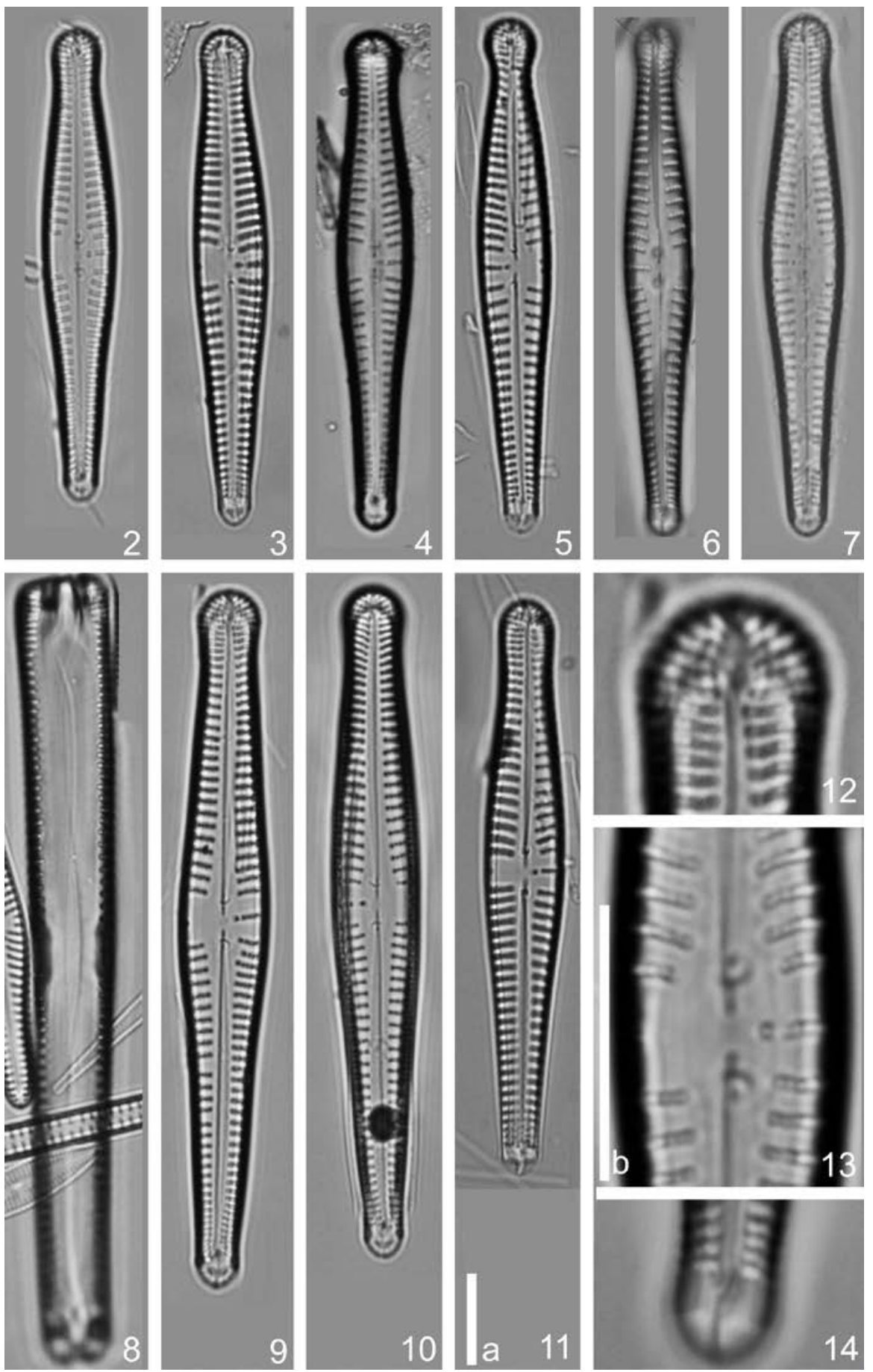

Figs 2-14. Gomphonema vibrio var. subcapitatum (Mayer) Lee in LM. 2-11 - valve size diminution series. 12 - rounded apical pole and silicified pseudoseptum, 13 - stigma located distant from long central stria, 14 - pseudoseptum at basal pole. Scale bars: $\mathrm{a}=10 \mu \mathrm{m}(2-11) ; \mathrm{b}=10 \mu \mathrm{m}(12-14)$. 

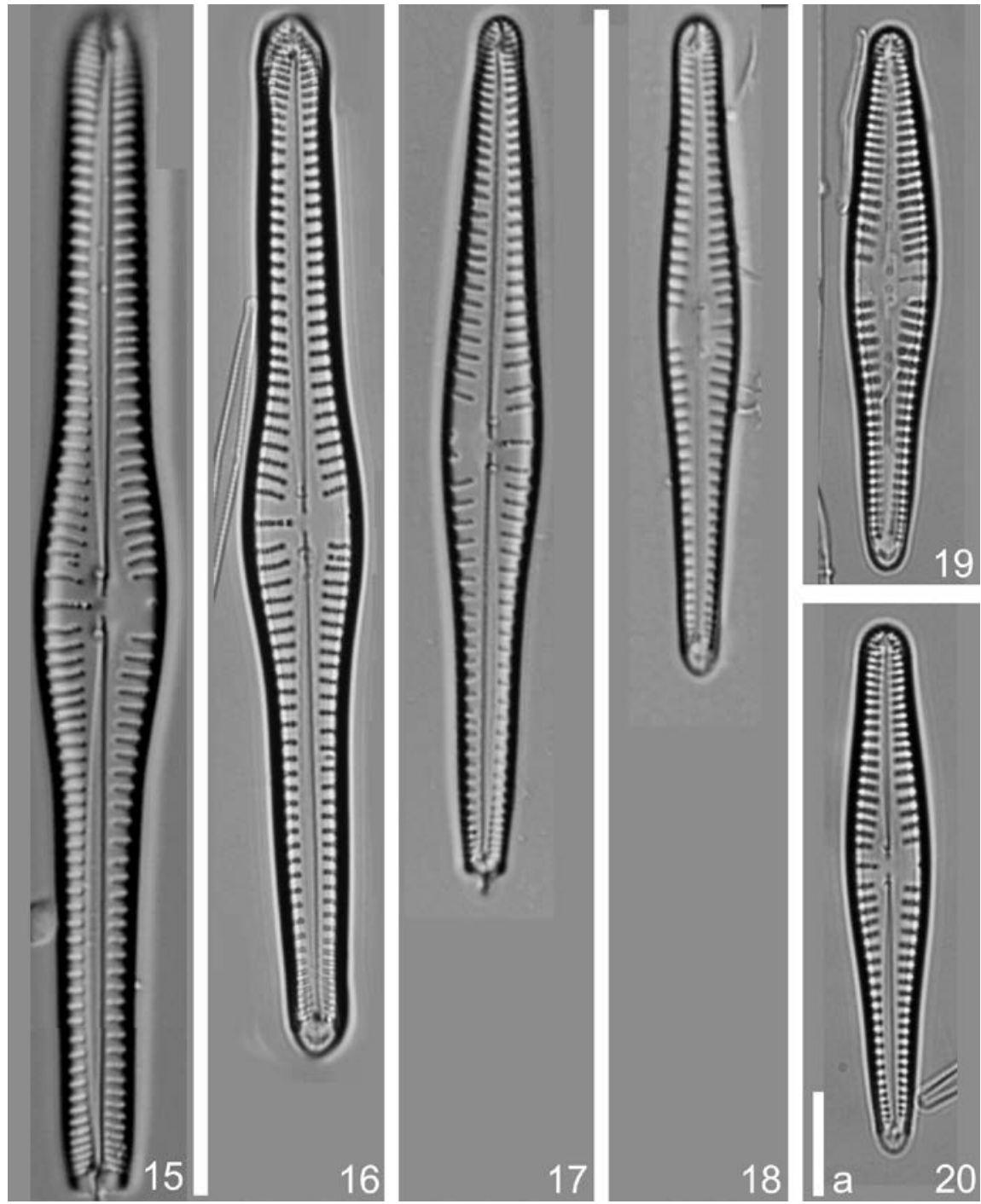

Figs 15-20. Morphological differences between Gomphonema vibrio Ehrenb. (15-18 - G. vibrio s.1.) from Muliczne Lake (15 \& 16), Okrągłe Lake $(17 \& 18)$ and $G$. vibrio s.str. from Muliczne Lake $(19 \& 20)$. Scale bar $=10 \mu \mathrm{m}$.

(spring, 1.5\%). The ionic composition of the water from the sampling sites with the highest abundance of G. vibrio var. subcapitatum (1.0-1.5\%) was as follows: phosphate $\left(\mathrm{PO}_{4}{ }^{3-}\right)<0.015 \mathrm{mg} \mathrm{L}^{-1}$, nitrate $\left(\mathrm{NO}_{3}^{-}\right)<0.38 \mathrm{mg} \mathrm{L}{ }^{-1}$, chlorine $\left(\mathrm{Cl}^{-}\right) 2.0-3.8 \mathrm{mg}$ $\mathrm{L}^{-1}$, calcium $\left(\mathrm{Ca}^{2+}\right) 24-51 \mathrm{mg} \mathrm{L}^{-1}$ and sulphate $\left(\mathrm{SO}_{4}{ }^{2-}\right)$ 6-24 $\mathrm{mg} \mathrm{L}^{-1}$; $\mathrm{pH}$ was $7.5-8.3$ and conductivity $160-330 \mu \mathrm{S} \mathrm{cm} \mathrm{L}{ }^{-1}$. Gomphonema vibrio var. subcapitatum was observed in lakes with medium water conductivity; this widens the range of tolerance for this taxon in comparison with data from other studies (Lee et al. 1992a, b).

The higher abundance of this taxon in waters with $\mathrm{pH}$ 7.5-8.3 and calcium content 24-51 mg L ${ }^{-1}$ suggests that it prefers more alkaline water but still has a broad tolerance for these factors ( $\mathrm{pH} 4.0-8.3$, calcium $0.85-68 \mathrm{mg} \mathrm{L}^{-1}$ ). In other studies it was identified in waters with pH 6-7 (Lee et al. 1992a, b). The highest abundance in waters with low content of nitrate and 
chlorine suggests that it is an indicator of good water quality.

The most abundant diatom taxa dominating ( $>10 \%$ share) the diatom assemblages with G. vibrio var. subcapitatum included Achnanthidium minutissimum (Kütz.) Czarn., Brachysira neoexilis Lange-Bert., Encyonopsis microcephala (Grunow) Krammer, Eunotia rhomboidea Hust., E. mucophila (Lange-Bert., Nörpel-Schempp \& Alles) Lange-Bert., E. cesatii (Rabenh.) Krammer, Fragilaria capucina Desm., F. delicatissima (W. Sm.) Lange-Bert., Gomphonema pumilum (Grunow) E. Reichardt \& Lange-Bert., Pseudostaurosira brevistriata (Grunow) D. M. Williams \& Round, Staurosirella pinnata (Ehrenb.) D. M. Williams \& Round and Tabellaria flocculosa (Roth) Kütz. Some of them are indicators of good water quality (Brachysira neoexilis, Fragilaria delicatissima) and some (e.g., Encyonopsis microcephala) have a broad range of water quality tolerance (Bąk et al. 2012).

Gomphomema vibrio var. subcapitatum can easily be confused with the more common $G$. vibrio Ehrenb. s.str. In Poland the latter has been reported from both mountain (e.g., Gutwiński 1898, 1914; Filarszky 1899, 1900) and lowland regions

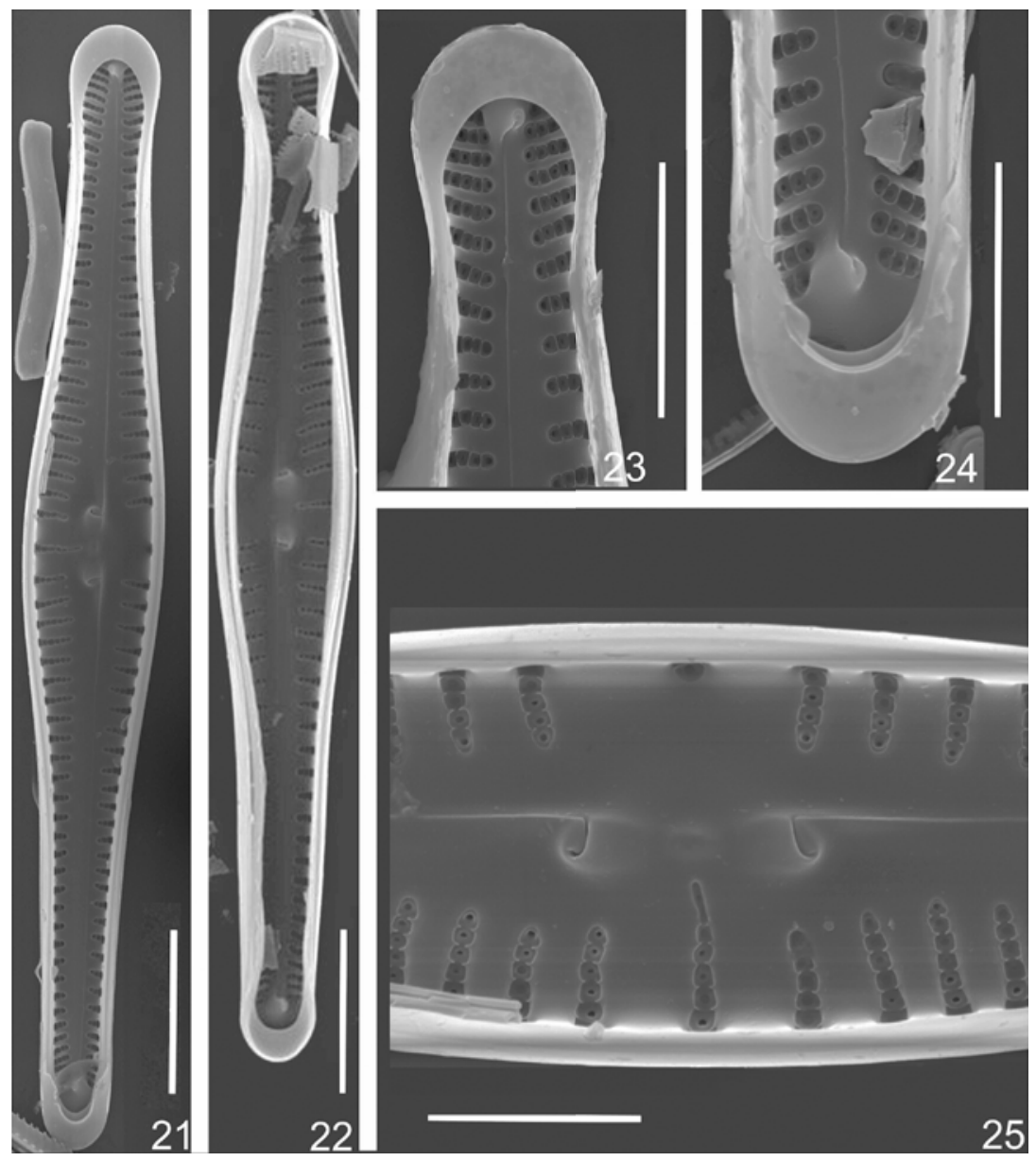

Figs 21-25. Gomphonema vibrio var. subcapitatum (Mayer) Lee in SEM internal view. 21 \& 22 - valves showing pseudosepta at both ends, $23 \& 24$ - slightly capitate headpole (23) and footpole (24) with much denser striae than in the mid-valvae, helictoglossa and pseudosepta, 25 - mid-valvae showing small stigma placed distant from long central stria and located in long groove. Scale bars: $21 \& 22=10 \mu \mathrm{m} ; 23-25=5 \mu \mathrm{m}$. 
(e.g., Wołoszyńska 1922; Pliński 1973; Zakryś 1980; Szymańska 1983; Ligowski 1986; Witkowski et al. 2011; Szczepocka \& Rakowska 2015; Siwek \& Pociask-Karteczka 2017). However, due to the lack of original materials or photographs it is difficult to state which morphological forms were observed. In the studied material I observed great morphological variety in G. vibrio. Some of these forms are shown in Figures 15-20.

Gomphonema vibrio var. subcapitatum was previously reported from its locus classicus in Germany (Mayer 1928, as G. intricatum var. vibrio f. subcapitatum) and from the United States of America (Lowe 1972, as G. intricatum var. vibrio f. subcapitatum; Patrick \& Reimer 1975), Japan (Skvortsow 1937, as G. nipponicum; Kobayasi et al. 2006) and Korea (Chung \& Kay 1969; Lee et al. 1992b). The morphology of G. vibrio var. subcapitatum from the USA differs from that of $G$. vibrio var. subcapitatum reported by Lee et al. (1992a) and those found in Poland. For example, it has a definitely broader headpole without a distinctly capitate apical pole, and the striae are located at similar distances from each other throughout the valvae (cf. Lowe 1972: pl. 4, 2). As that observation (Lowe 1972) was based on one valve only, the problem of specimen identity is still open.

Acknowledgements. I am indebted to Professor Agata Z. Wojtal and for her help, valuable suggestions and advice, comments on taxonomical problems, and critical reading of the manuscript. I thank Hanna Szymańska, Hanna Werblan-Jakubiec, Bożena Zakryś and Włodzimierz Winiarski, employees of Wigry National Park, for generous help with field work and for other assistance, Anna Latkiewicz (Institute of Geological Sciences of the Jagiellonian University) for SEM analyses, and the anonymous reviewers for constructive suggestions. This work was supported by the Institute of Nature Conservation, Polish Academy of Sciences (Kraków, Poland) through grant funding for $\mathrm{PhD}$ students and through the Institute's statutory funds.

\section{REFERENCES}

Bąk M., Witkowski A., ŻElazna-Wieczorek J., Wojtal A. Z., Szczepocka E., Szulc A. \& Szulc B. 2012. Klucz do oznaczania okrzemek $w$ fitobentosie na potrzeby oceny stanu ekologicznego wód powierzchniowych w Polsce. Biblioteka Monitoringu Środowiska, Warszawa. http://www. gios.gov.pl/images/dokumenty/raporty/Klucz_do_oznaczania_okrzemek_w_fitobentosie.pdf.

Chung Y. H. \& KaY E. S. 1969. A study on the microflora of the Han river, IV. Korean J. Limn. 2: 9-30.

FILARSZKY N. 1899. Adatok a Pieninek Moszatvegetatiójehoz - Contribution to the knowledge of algae in the Pieniny Mts. Math. Természettud. Közlem. 27: 723-800.

FilARSZKY N. \& FilARSZKY F. 1900. Beiträge zur Algenvegetation des Pieninen Gebirges auf ungarischer Seite. Hedwigia 39: $133-148$.

GóRniaK A. 2006. Jeziora Wigierskiego Parku Narodowego. Aktualna jakość i trofia wód. Uniwersytet w Białymstoku, Białystok.

GutwiŃski R. 1898. Algae in itinere per montem Babia Góra collectae. Spraw. Komis. Fizjogr. 33: 191-203.

GutwiŃski R. 1914. Über die Algenflora und das Plankton des Tatra-Sees "Morskie Oko". Kosmos 38(10-12): 1426-1437.

Hofmann G., Werum M. \& Lange-Bertalot H. 2011. Diatomeen im Süßwasser-Benthos von Mitteleuropa. Koeltz Scientific Books, Königstein.

Kobayasi H., Masahiko I., Mayama S., Nagumo T. \& Osada K. 2006. H. Kobayasi's Atlas of Japanese diatoms based on electron microscopy. Uchida Rokakuho Publishing Co., Ltd., Tokyo.

Lee J. H., Gotoh T. \& Chung J. 1992a. A study of diatom species Gomphonema vibrio Ehr. var. subcapitatum (Mayer) Lee, comb. nov. Korean Journal of Phycology 7(1): 79-87.

Lee J. H., Gotoh T. \& Chung J. 1992b. Diatoms of Yungchun Dam Reservoir and its tributaries, Kyung Pook Prefecture, Korea. Diatom 7: 45-70.

Ligowski R. 1986. Sessile algae in lower sections of the main tributaries of the Widawka River. Acta Univ. Lodz., Folia Bot. 4: 171-202.

Lowe R. L. 1972. Notes on Iowa diatoms X: new and rare diatoms. Proc. Iowa Acad. Sci. 79(2): 66-69.

Mayer A. 1928. Die bayerischen Gomphonemen. Denk. Bayer. Bot. Ges. Regensburg 17: 83-128.

Patrick R. \& Reimer C. W. 1975. The diatoms of the United States exclusive of Alaska and Hawaii. 2(1). Entomoneidaceae, Cymbellaceae, Gomphonemaceae, Epithemiaceae. The Academy of Natural Sciences of Philadelphia, Philadelphia.

PicińSKa-Faltynowicz J. \& BŁachuta J. 2010. Methodological guidelines for assessing the ecological status of bodies of rivers and lakes and the ecological potential of artificial and heavily modified bodies of running waters in Poland on the basis of phytobenthos surveys. Chief Inspectorate for Environmental Protection, Wrocław (in Polish). 
PliŃSKi M. 1973. The algae of salt marshes near Łęczyca, Central Poland. Monogr. Bot. 39: 3-88.

Reichardt E. \& Lange-Bertalot H. 1991. Taxonomische Revision des Artenkomplexes um Gomphonoma angustumG. dichotomum-G. intricatum-G. vibrio und ähnliche Taxa (Bacillariophyceae). Nova Hedwigia 53(3-4): 519-544.

Siwek J. \& Pociask-Karteczka J. 2017. Springs in SouthCentral Poland: changes and threats. Episodes 40(1): 45-46.

Skvortsov B.W. 1937. Diatoms from Kizaki Lake, Honshu Island, Nippon. Philippine Journal of Science 61(1): 9-73.

Szczepocka E. \& RaKowsKa B. 2015. Diatoms in the biological assessment of the ecological state of waters using the Czarna Staszowska River as an example. Oceanological and Hydrobiological Studies 44: 254-266.
SZYMAŃSKa H. 1983. Periphytic algal communities in four lakes of the Suwałki Lake District in Poland. Acta Hydrobiol. 25/26(3/4): 359-388.

WitKowski A., RadZIEJEWSKa T., WAWrZyNiaK-WydrowSKA B., LANGE-BERTALOT H., BĄK M. \& GelbRECht J. 2011. Living on the $\mathrm{pH}$ edge: diatom assemblages of low- $\mathrm{pH}$ lakes in western Pomerania (NW Poland). In: J. SECKBACH \& P. Kociolek (eds), The Diatom World, pp. 365-384. Springer, Dordrecht, Heidelberg, London, New York.

WoloszyŃSKa J. 1922. Winter-Flora der Morenenquellen des Wigry Sees. Kosmos 47(1-3): 305-326 (in Polish with German summary).

ZAKRYŚ B. 1980. Qualitative and quantitative relations in peryphiton diatoms of lake Krejwelek, Suwałki Lake District. Fragm. Florist. Geobot. 26(1): 141-158 (in Polish with English summary). 